\title{
Civil Society under Martial Rule: Comparing the state-civil society nexus under the rule of two dictators in Pakistan
}

\author{
Hina Khan* \\ Moiz Khan**
}

\begin{abstract}
Contemporary discourse on civil society asserts democracy as a precondition for a successful working of civil society and a vibrant civil society for a smooth working of democracy. Yet there have been exceptions. On one hand some predominantly authoritarian regimes around the world are said to have harbored vibrant civil societies such as some countries of East Asia and Latin America. In this context, this paper overviews the growth and development of civil society in Pakistan during the rule of two military dictators in Pakistan viz. Ayub Khan (1958-1969) and Zia-ul-Haq (1977-1988) in the light of statecivil society models of conflict and coordination. It further seeks to explore: How those dictators treated the civil society in Pakistan? What was the response of civil society towards the dictatorial rule? And can we draw some parallels in the working of this nexus during the two eras?
\end{abstract}

Keywords: State-Civil Society nexus, Democracy, Authoritarianism, Martial Rule, Military regimes, civil society, nonprofit sector, Civil Society Organizations (CSOs), Pakistan, General Ayub Khan and General Zia-ul-Haq

*Dr. Hina Khan is an Assistant Professor at the Department of General History, University of Karachi. Her particular field of specialization is statecivil society relations in Pakistan and the world at large.

** Assistant Professor, Department of General History, University of Karachi 
In 1947, Pakistan emerged as an independent Muslim state formed through a tedious constitutional struggle wrought with hard political bargains and compromises. The initial years of the country reflect this struggle in the form of a general consensus on a democratic republic though with various views on its basic edifice. While the constitution of the country could not be drafted for the first nine years, the initial problems of a poor new state with millions of refugees and scarce resources haunted the first decade. Those turbulent years also witnessed a slow but steady growth of civil society coming up to share the burden of the state. However, the eleventh year of independence brought the imposition of country-wide Martial Law - a trend which was to continue for long spells in the years to come. ${ }^{1}$ The nascent civil society had to suffer the roll-back of democracy and to readjust to the new realities of the martial rule. Harold Gould asserts that the civil society 'failed in Pakistan because political power quickly lapsed into the hands of a coterie of generals, mullahs, landlords and bureaucrats who hijacked the tremulous beginnings of popular government and opted instead for military dictatorship legitimized by ideological jingoism'.2

How far the civil society 'failed' and how far it managed to readjust itself to the new realities is a matter of little consensus. In this backdrop, the purpose of this paper is to analyze the role of civil society in Pakistan under two periods of military rule: Ayub's era (1958-69) and Zia era (1977-88). It will particularly tend to explore the state-civil society relations during each of these eras and the overall performance of the civil society organizations in the light of the existing theories of conflict and coordination or interdependence between the state and the civil society. Historically, the state-civil society relationship has itself been problematic and a source of theoretical debate among the scholars. But when it comes to the dictatorial regimes the survival and working of civil society becomes more challenging and thus open to more contest. Yet there is evidence that civil society survives, works and even coordinates with some dictatorial regimes. At least some types of civil society organizations have known to enjoy patronage of

1 The first constitution of the country enacted in 1956 could survive for hardly two years before the imposition of Martial law in 1958 by Field Martial Ayub Khan who ruled the country for next ten years. The trend of military interventions in politics continued with the overthrow of Ayub Khan by the next General in line, Yahya (1969), then the coup by General Zia (1977), and finally General Musharaf (1999) rolling back the political regimes preceding them.

2 Harold Gould, "Civil Society in Pakistan and India: A study in contrast", Briefs of the Centre for South Asian Studies, University of Virginia, Jan. 27, 2007. 
dictators. In this context the paper in divided into three sections: the first being a literary overview of the concept and conditions of civil society under authoritarian regimes as studied by some scholars with respect to various regions of the world; The second and third sections explore the working of civil society and the challenges it faced under the two military regimes in Pakistan. The conclusive section tends to draw some parallels between the two regimes in the light of the findings of this study with the help of theoretical understanding developed in the first section. At this point, before going into historical details, it seems imperative to have a theoretical overview for the study:

\section{Section I: \\ Civil Society under the authoritarian regimes - A literary overview of the concept and its underpinnings}

Since the inception of its modern concept in the enlightenment era, the civil society has been understood as bulwark against the royal absolutism. To Kant it was a 'sphere meant to contain and check the arbitrary powers of monarchical rulers'; 3 to Vaclav Havel it is the 'domain of anti-politics'. ${ }^{4}$ Nineteenth and twentieth century liberal thinkers endorsed this 'conflict model' by asserting that the civil society by its very nature stands in opposition to the state wherein a strong civil society entails a weak state and vice-versa. In this way there is a kind of 'zero-sum game' between the state and the civil society. Ernest Gellner views civil society as 'a set of diverse non-governmental institutions, which counter-balance the state but do not prevent the state from fulfilling its role of keeper of the peace and arbitrator between major interests' 5 Conversely, there is another model wherein the state and the civil society are interdependent and hence work in coordination with each other. Sometimes referred to as 'interdependence model' it asserts that the civil society organizations often push 'for the

3 Alix A. Cohen, 'Kant's Concept Of Freedom And The Human Sciences', Canadian Journal Of Philosophy, Vol. 39, No. 1, p. 119

4 Vuclav Havel the former president of Czechoslovakia and later the Czech Republic and a dissident socialist was a staunch supporter of civil society as a bastion against tyranny. See Vuclav Havel: Civil Society plays an important role in the enlargement (of EU), Euracity, February 16, 2000 (updated 2010) https://www.euractiv.com/section/ enlargement/news/havel-civil-society-plays-important-role-in-enlargement/ accessed 3-4-2011

5 Ernest Gellner, Conditions of Liberty: Civil Society and its Rivals, London: Hamish Hamilton, 1994, pp. 4-5 
extension of state services' while the state plays a supportive role by subsidizing through providing grants, exempting taxes and simplifying laws to allow smooth working and development of the civil society organizations (CSOs). ${ }^{6}$ This model is often preferred by the service delivery and development organizations which try to avoid unnecessary stand-offs and prefer a complementary partnership with the state where both partners enter into a win-win situation. Apparently, this also minimizes the political role of the civil society as advocated by the Neo-Conservatives. However, studies like one by Robert Weller and Hsin-huang Michael Hsiao reveal the complex forms of interlocking of civil society with different forms of state power, and suggest that despite these ties, civil society can exert a transformative power in politics. ${ }^{7}$

Nevertheless, in case of an authoritarian government this relationship carries more connotations. A strong civil society has been understood to be the basis of a democratic system. ${ }^{8}$ To Diamond, it provides a platform for the people to express their say and to participate in political matters and to keep state officials accountable. ${ }^{9}$ However, some scholars have pointed out the cases where robust civil societies have survived without appropriate liberal democratic set-ups. ${ }^{10}$ In fact totalitarian regimes usually have no place for civil society but they may allow it to advance their own goals in the society. For instance, the welfare and service delivery CSOs are often allowed and even facilitated in authoritarian regimes as an extension of state's own institutions. Further, authoritarian rulers rather tend to atomize their respective societies in order to reassure a de-politicization of society and reorientation of active citizens to social work. In such cases free public spaces

6 D.W. Brinkerhoff, 'Exploring State-Civil Society Collaboration: Policy Partnerships in Developing Countries', Nonprofit and Voluntary Sector Quaterly, Vol. 28, No. 1 (December 1, 1999)

7 P. C. C. Huang, “'Public Sphere', 'Civil Society' in China: The Third Realm between State and Society", Modern China, vol. 19, no. 2 1993, pp. 216-40; and H. B.Chamberlain, "On the Search for Civil Society in China", Modern China, vol. 19, no. 2 1993, pp. 199-215, cited by Tanvir Anjum, op.cit. p. 98

8 See Alexis de Tocqueville, Democracy in America (translated by Henry Reeve), Penn. State Electronic Classic Series, pp. 77- 86, https://www.academia.edu/4780188 DDemocracy in America By Alexis de Tocqueville A Penn State Electronic Classics Series Publication accessed 20-2-2009;

9 Larry Diamond, Developing Democracy - Towards Consolidation, (Baltimore: JHU Press,1999) 221-227

10 For instance, Sunil Khilnani, 'The development of civil society' in Sudipta Kaviraj and Sunil Khilnani (eds.) Civil Society - History and Possibilities, (Cambridge: Cambridge University Press, 2001) 25-29 
will not be tolerated and the citizens' interests will be reoriented to 'exclusively private goals'. ${ }^{11}$ Thus authoritarian regimes may help the 'multiplication of different organizations' while the 'cessation of ...political activity enhances the autonomy of such organizations to define and pursue their own interests...' Due to this reason, the dictatorial regimes at times abstain from completely destroying the political spaces but rather tend to shift the 'locus of political activity to nonparty arenas by effectively proscribing traditional political-part activity'.12

This kind of diversion, along with other authoritarian tactics tends to perpetuate and strengthen the dictatorship. However, such regimes are never completely invulnerable. Dictators are often 'precariously positioned and their inability to 'balance their rivals' may lead to their eventual fall.13 Civil society is one of those rivals of dictatorship which they try to balance and use in their favor.

In the light of the above discussion the next two sections will overview the working of civil society and its manipulation under the dictatorial regimes of Ayub Khan and Zia-ul-Haq in Pakistan with particular reference to the challenges faced by the civil society; state's policies towards civil society; and the impact of state policies on the growth and working of civil society.

\section{Section 2:}

\section{Under the First Martial Rule - Ayub's Management of the Civil Society}

During the first decade of Pakistan, an emerging civil society, mostly trained during the freedom struggle, showed its presence in a wide variety of fields from refugee rehabilitation to women empowerment to trade union activity. The early governments have accepted the role of civil society as a partner in facing the tremendous problems of the new state. The result was a coordination or interdependence model of state-civil society nexus. But this could not continue for a long time.

11 Guillermo O'Donnel and Philippe C. Schmitter, Transitions from Authoritarian Rule Tentative conclusions about uncertain democracies, (Baltimore: Johns Hopkins University Press, 1986,2013) 55-57

12 Philip D. Oxhorn, Organizing Civil Society - The Popular Sectors and the Struggle for Democracy in Chile, (Pennsylvania: Pennsylvania State University Press, 1995) 5-7

13 Andrew Heiss, 'The Failed Management of a Dying Regime: Hosni Mubarak, Egypt's National Democratic Party, and the January 25 Revolution', https://www.andrewheiss.com/research/heiss-2012/ accessed 29-7-2013 


\section{a. New Challenges:}

Ayub Khan's coup against the fragile democratic rule in October 1958 and the imposition of martial law brought to light some new challenges regarding the role of civil society: the challenge of finding a suitable modus operandi to deal with a totally unrepresentative, highly centralized government; the challenge of keeping relations with now defunct political parties; the challenge of standing for fundamental human rights; and the challenge of keeping the public aware of their situation in the absence of a free media.

But foremost was the challenge of survival. The ban over the political parties and all political activity stifled the growth of the progressive sections. Some active organizations and the trade unions were banned and their offices sealed. Arrests were common. The ministry of Social Welfare which had many public leaders and activists with strong political affiliations, working in National and Provincial Councils of Social Welfare, was virtually purged of its 'non-official' (politically oriented) members. All this retarded the free growth of civil society. The net result of this policy was a retardation of the role and dimensions of civil society to a secondary and at best a supplementary level vis-à-vis the state.

\section{b. State Policies towards Civil Society:}

On the part of the regime, the main policy towards the civil society included

- Regularization: In fact there was a long-felt need of legislation for the regularization of voluntary and nonprofit organizations which have been mushrooming since the British period. There were several laws including the Societies Registration Act of 1860 but none of those laws covered all types of CSOs. Even the Act of 1860 was given to facilitate scientific and literary organizations. ${ }^{14}$ The Voluntary Social Welfare Agencies (Registration and Control) Ordinance 1961provided a more suitable law to streamline the wide array of CSOs working in the country along with a tool of control to the government. ${ }^{15}$

14 See the Societies Registration Act, 1860 (Act XXI of 1860 - original document) https://www.ma-

law.org.pk/pdflaw/The\%20Societies\%20Registration\%20Act\%201860.pdf accessed 9$9-2012$

15 See The Voluntary Social Welfare Agencies (Registration and Control) Ordinance 1961 (Ordinance No. XLVI of 1961- Original Document) http://www.ilo.org/dyn/natlex/docs/ELECTRONIC/81785/88956/F1282834913/PAK 81785.pdf 
Nevertheless, the usefulness of the law is evident from the fact that more organizations were registered under it as compared to the Societies Act of 1860. See the figure below:

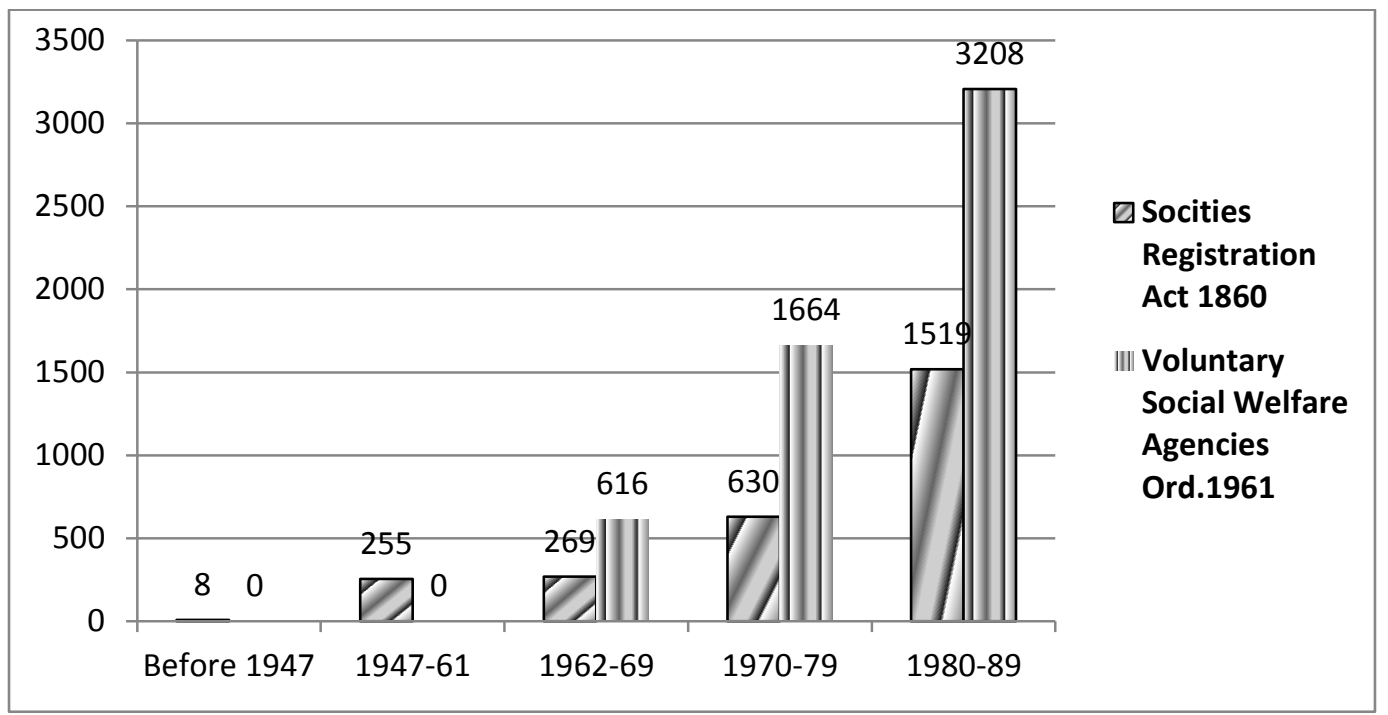

Figure 1: Registered Growth Of Npos In Pakistan Under Two Major Laws (Up To 1990)

Source: Adapted from Ministry of Planning and Development, Government of Pakistan, Survey of NGOs in the Field of Social Services- Pakistan, vol. 1, Survey Report, Lahore: HRH Associates, 1990, fig. 6 \& 7

- Grants-in-Aid: The Grants-in-Aid Program was initiated to support as well as to strictly monitor the registered agencies, whose services to the community were considered of a sufficiently high (and harmless) quality. A large number of newly registered organizations under the Voluntary Social Welfare Agencies Ordinance (1961) received encouragement and substantial Grants-in-Aid.

- Encouragement of Welfare and Service-Oriented CSOs: The major beneficiaries within the civil society were the welfare-oriented organizations that managed to find ample space for their activities. In fact many of these were the long established and esteemed organizations with a reputation of sincerity, vibrancy, and a committed non-political agenda.

- Crackdown on trade unions, student's organizations and advocacy-oriented organizations: Along with political parties, trade 
unions and students organizations were also banned. In fact labor movement in Pakistan was entering a relatively advanced stage by 1958 when it was disrupted by the Martial Law authorities. Though organizations working for women's welfare were encouraged, 'empowerment' increasingly became an irritating term. Hence, the United Front for Women's Rights established in 1950s was banned. 'Activists dispersed, women's issues dropped off the radar screen and in the decade 1957-1968 the struggle for women's rights ceased to be visible as a movement. Lobbying for women's rights, such as existed, was carried out via informal social networks by women connected to and therefore able to access the corridors of power in government of Pakistan'.16

- Crackdown on Sufi shrines: Surprisingly, the paranoia of the government was visible when the religious endowments and sufi shrines which had been centers of nonprofit activity through centuries, were taken over and controlled by the government under its Ministry of Religious Affairs thanks to the official dislike of the massive congregations which used to assemble at such places. This however led to the growth of a number of voluntary associations, patronized by the custodians and the followers of the shrines which served the shrines and managed donations from those who did not trust the government officials. This policy was bitterly criticized as "unjustified government interference". 17

\section{c. Impacts of State Policies on the growth and working Civil Society:}

First, registration helped streamlining CSOs. Some of such welfare organizations which were registered and patronized through the West Pakistan Council for Social Work, included the West Pakistan Society for the Welfare of the Crippled, Recreation Association for West Pakistan, Children's Home, Al Shifa Trust (1967) for the relief and rehabilitation of polio victims etc. ${ }^{18}$ In Punjab, several new organizations appeared like Behbud

16 Fareeda Shaheed, "The Women's Movement in Pakistan, Challenges and Achievements", in Amrita Basu (ed), Rethinking Global Women's Movements, Routledge, This paper draws on work, discussions and papers of the research consortium, Women's Empowerment in Muslim Contexts: Gender poverty and democratization from the inside out led by the Southeast Asia Research Centre of City University. See www.wemc.hk.com accessed 412- 2012

17 Shahjahanpuri and Siddiqui, op.cit, 116

18 Dr. Rabiya Abbas, Social Welfare Administration in Pakistan, (Lahore: Alhamra Academy, 1969),17-20 
Foundation, Rawalpindi (1967) working in education, health, community development, family planning, credit provision, and income generation etc. Side by side the older organizations like Anjuman-e-Himayat-e-Islam, etc, worked for the welfare of their targeted groups.

Second, many new education and literary institutions also made their impact on society. Enthusiasm to educate the newly independent nation was still alive. Though many of these can be counted as faith-based organizations carrying Islamic nomenclature like 'millet" (the Islamic nation), ${ }^{19}$ Islamia etc, and many concentrated on promoting Islamic values and education, there was a clear orientation towards modern education in at least some of such organizations. For instance, AlMarkaz-e-Islami, Karachi was a vigorous outfit which had more than forty sub-organizations all over the world. Particularly one of its sub-organization, Jamia Aleemia Karachi (estb. 1958), catered for the Islamic, modern and vocational education of its students. Its curriculum included Arabic and English learning and seminars, conferences and discussions were a regular part of it. ${ }^{20}$. Similarly, Idara-eMuarif-e-Milli, Lahore, (estb. 1966), aimed at promotion of various fields of knowledge, including literature, linguistics, history, politics, and Islamic studies. Its founders and workers included personalities like Justice Mohammad Muneer, Justice Badeeuzzaman Keekaos, Aga Shorish Kashmiri, Majeed Nizami, Ahsan Danish, and Rasheed Akhtar Nadvi. ${ }^{21}$ Some new organizations also emerged such as Idara-e-Nashr-e-Uloom-e-Islami, Jhang, Punjab (1968) ${ }^{22}$, Aalami Idara-e-Ishaat-e-Uloom-e-Islamia Multan, 1965, Idara-e-Maarif-e-Islamia Karachi (1963), Children Quran Society Lahore (1967), etc.

Third, some Muslim ethnic communities like Memons, Gujratis, Bohris, Ismailis, Punjabis, Kashmiris etc. also took substantial interest in social welfare. Services of many community based organizations like Ayesha

19 Perhaps Islamic nomenclature protected some of these organizations from the state's wrath despite the progressive debates and poetry presented in their meetings.

20 Some of the guest speakers in these seminars included Justice Qadeeruddin, I. H. Qureshi, A. K. Brohi, Kausar Niazi etc. Minaret was the English monthly organ of the Jamia. Abu Salman Shahjahanpuri and Amir-ul-Islam Siddiqui, Barr-e-Sagheer Pak-o-Hind ke Ilmi, Adabi aur Taleemi Idare - Mujalla-e-Ilm-o-Agahi. (Urdu) (Karachi: Government National College, 1975) 135-136

21 The organizations published several books on important topics such as Khilafat-eRashida mein Jamhoori Iqdar (Democratic Values in the Pious Caliphate) Ibid. p. 109

22 Ibid, p. 153 
Bawani Academy Waqf Karachi (1957-58), Rangoonwala Foundation (1967), Kathiawari and Memon Associations, Punjabi Sodagaran (Traders) Association etc for the welfare and relief of distressed people are also worth mentioning. The role played by the Aga Khan Foundation (AKF, 1967), in the promotion of education, health care and community development first in Karachi and later in the Northern Areas of Pakistan, including Gilgit, Skardu, Hunza, Nagar, Chitral and some parts of Baluchistan is an exemplary one. Many of these were purely localized and grass-root level organizations, while some showed wider field of activity.

Fourth, the fateful wars of 1965 and 1971 and the subsequent dismemberment of Pakistan (1971) regardless of their nature, dynamics and results ${ }^{23}$, rejuvenated the nationalist patriotic feelings all over the country. Civil Society though stifled by the martial rule was invigorated with a new purpose responding with active services. More or less all of the above mentioned organizations and many others like Girl Guides, Scouts, Red Crescent society, Lions' and Rotary Clubs etc. stood in the moment of need to serve the nation in providing relief, collecting funds and provisions, and extending health care to the soldiers, their families and victims of war and violence. Likewise, that was also a period of high activity for the individual philanthropy ranging from public morale building to supporting war relief efforts. For all such efforts the increasingly isolated government was more than willing to appreciate and cooperate.

Fifth, Ayub's era though referred to as the so-called 'decade of development' showing tremendous agricultural and industrial boom, and the highly capital-intensive economic growth was apparently hailed internationally, the perils of unequal development loomed large in the form of regional and ethnic tensions (which eventually led to the dismemberment of Pakistan in $1971)^{24}$ While the indices showed 6\% to 7\% GDP growth, the gap between the haves and the have-nots was widening with little change in the living standards of the masses. ${ }^{25}$ This, together with the post 1965 war economic crunch, inevitably led to an open class conflict providing a fertile ground for

24 The entire emphasis of state's investment and encouragement was concentrated on a few areas (Karachi and Punjab) and a few groups (the 22 families). For detailes see Ishrat Hussain, Pakistan and Afghanistan: Domestic Pressures and Regional Threats, Role of Politics in Pakistan's Economy, Vol. 63, No. 1, Fall/Winter 2009 page 1-18, at http://jia.sipa.columbia.edu/role-politics-pakistans-economy-0.

25 See S. Akbar Zaidi, Issues in Pakistan's Economy, Michigan: Oxford University Press, 1999, pp. 29-33. 
the rise of the Progressive Movement. The rapid industrialization increased the number of trade unions by and labor organizations by 1967. Most of them had leftist leanings and were openly criticizing the anti-people and anti-labor internal policies and increasingly pro-west foreign policies of the government. This resulted in a second crackdown on trade unions and legislation for their strict control. ${ }^{26}$ These organizations took an active part in the anti-Ayub movement.

Sixth, martial Law also suppressed the already stifled student's movement. ${ }^{27}$ However, by 1960, the National Students' Federation (NSF) which was founded as a pro-establishment group had transformed into the country's leading progressive student organization. . It also had a wider and more varied rank and file including communists, socialists, left-liberals and socialdemocrats. Almost simultaneously, the Islami Jamiat-e-Talaba (IJT), the student wing of the rightist political cum religious party Jamaat-e-Islami had also expanded. Students' Unions elections were bitterly contested by the two, though mostly won by the NSF. Till the end of the military rule these two groups remained the major rivals in students unions' elections in Punjab and Karachi reflecting two distinct schools of thought while the rightist MSF remained divided and confused and the leftist DSF went almost dormant. However, the Anti-Ayub movement activated many students' organizations. ${ }^{28}$

The anti-Ayub movement led to another martial law by General Mohammad Yahya Khan in 1969. Yehya's short term (1969-71) is distinguished with three catastrophic events: the first and last general elections of the country (1970); the civil war in the East Pakistan; and the break-up of the country following the Indo-Pakistan War in late 1971. Civil society though continuously organized patriotic campaigns, the fate of the country could not be reverted.

26 For instance, the Industrial Relations Ordinance (1969) enforced strict regulations for the trade unions and made strikes almost impossible.

27 The DSF and the CPP were banned since 1954. As early as 1959, a CPP activist and a sympathizer of DSF was arrested by the Punjab police and tortured to death. Both groups were losing vigor by the turn of the decade.

28 In fact the agitation started with a demonstration for some nonpolitical demands by the Polytechnic Institute of Rawalpindi that later took a political turn. See Hasan Askari Rizvi, 2000, p. 117 


\section{Section 3:}

\section{Civil Society under General Zia-ul-Haq - the ironic boom (1977-1988)}

After a six-year interlude of democracy (1971-1977) when the postdismemberment political government of Z.A. Bhutto and his Pakistan Peoples' Party (PPP) rose and fell, the country lapsed into another period of military dictatorship. In fact the anti-Bhutto agitation culminated in the military coup and imposition of Martial Law by General Mohammad Zia-ulHaq in 1977. Political parties and party-based politics both were rendered defunct.

\section{a. New Challenges:}

The political leadership, particularly that belonging to the PPP and some leftist groups, was either arrested or exiled creating a vast vacuum between the state and the society. This vacuum presented an opportunity to the civil society. Further various internal and international changes also challenged the civil society as many new vistas of nonprofit activity were opened. Particularly, the Soviet intervention in Afghanistan had completely changed the socio-political scenario of the country and in the new scenario civil society had a new role to play. Rehabilitation of three to four million Afghan refugees was itself a major task; shrinking welfare role of the state shifted more responsibilities upon the philanthropic and voluntary social welfare organizations; response to the Islamization drive of the Zia regime was also important; then the oppression of marginalized sections of society was challenging the conscience of the rights organizations and media; and finally survival in face of a totalitarian regime which had no tolerance for dissent was the most pressing challenge.

\section{b. State Policies towards Civil Society:}

\section{- Conflict and Coordination at the same time}

Once again the criterion for the state patronage was same: "Yes" to service oriented and "no" to advocacy and rights oriented organizations. In fact this discrimination was so stark this time that while the former enjoyed highest levels of state support and encouragement, the latter suffered worst forms of state suppression. Many liberal-minded groups which started a struggle against authoritarianism and religious extremism in the country were suppressed brutally by arrests, executions, public floggings complimented with fatwas (religious decrees) and charges of kufr (infidelity) and conspiracy against the Islamic state. 
- Frontline state and the frontline civil society

Pakistan assumed the frontline status against the Soviet intervention in Afghanistan since 1979. The west-sponsored Jihad against the Soviet forces in Afghanistan resulted in the downpour of Afghan refugees to Pakistan. Pakistan while dispensing its 'frontline' responsibilities of supporting the Jihad efforts as well as rehabilitation and indoctrination of the Afghan refugees also needed internal partners to carry out the noble task. Civil society was encouraged to play that role. The religious organizations working to provide the ideological, financial, political and military support to the Afghan Jihadi outfits were encouraged with tax exemptions and generous grants along with provision of all required facilities. Similarly, the CSOs working for humanitarian relief to the refugees were also patronized.

\section{- Islamization required support organizations:}

The vigorous Islamization program aimed apparently at creating a 'true Islamic state as promised by the creators of Pakistan' but actually to legitimize the military regime internally and internationally as a champion of Islam and Islamic jihad. In Pakistan "it is a part of repetitive history to bring in Islam as being endangered"29. The anti-Bhutto movement of 1977 is a testimony when a number of variedly oriented anti-Bhutto parties used this idea, aspiring to establish "Nizam-e-Mustafa" (the way of Mustafa, the prophet of Islam) criticized Bhutto more for his "un-Islamic ways" rather than his undemocratic policies. General Zia, thus obliging the anti-Bhutto parties by offering them a power-sharing arrangement in which the state would act as senior partner, while the former "would gain from state patronage and enjoy a modicum of political activity" 30 Several Islamic parties were co-opted in a hand-picked parliament (the Majlis-e-Shura) and a civilian cabinet while their student and women wings dominated the educational and social institutions. Particularly the IJT that was patronized by the military regime became the main vehicle of state interest in Karachi and Punjab Universities and colleges.

29 Mirza Irshad Ali Beg, Democracy Displaced in Pakistan, Karachi: Research and Development Publications,1998, p. 105

30 Rasool Baksh Raes, State, Society and Democratic Change in Pakistan, Karachi: Oxford University Press, 1997, 117-118 
The measures for Islamization included establishment of the Islamic Ideology Council ${ }^{31}$ and Shariat Benches in all the High Courts and an Appellate Bench at the Supreme Court, and a Federal Shariat (Islamic canon law) Court in $1979^{32}$ This provided an exclusive representation to the Ulema (religious scholars) in law matters and indirectly helped in rejuvenation of the Islamic Madrassah system which was losing strength and significance during the last decades. The graduates from the religious institutions were in demand in the Islamization process. Unfortunately, in this new role, the need to revive the orthodox teaching system and its old curriculum was never felt.

Another measure was the introduction of Zakat and Ushr'33(1980). A Zakat fund was established with the initial amount of Rs. 2,250 million (partly donated by Saudi Arabia and UAE) for the purpose of supporting widows, orphans and other needy persons. Many welfare oriented voluntary organizations, religious and secular both, were provided grants from this fund. However, there existed a degree of discontent regarding the system of distribution of these grants and the laborious process of account keeping and audits attached to it, the cost of which at times exceeded the grant itself. ${ }^{34}$

\section{- State-failure in providing public goods to maximum numbers}

With the rise of neo-liberal economic paradigm around the world, the welfare role of the Pakistani state also shrank. Further, with the preoccupation in Jihad and Islamization Zia regime had little time, resource or interest to look after the down-trodden. Basic facilities of life were not available to the populous and ethnically diverse slums. Further, the state also failed to provide another essential public good - security to the increasingly growing city dwellers. Civil society was expected to fill the gap left by the state.

31 The Council had an advisory status in the Islamization policy. It was also entrusted with the task to review the existing laws and bring them into conformity with the Islamic injunctions as prescribed in the Quran and Sunnah.

32 The Shariat Court was later given constitutional protection where appeals could be made against any law or administrative action if it was considered un-Islamic.

33 Zakat is a compulsory annual alms of $2.5 \%$ of one's property and cash every Muslim has to give in the way of God. Ushr is a tax of $10 \%$ of the agricultural produce to be paid to the Islamic state.

34 This was shared by Shah Turab-ul-Haq Qadri, the Nazim of Darul Ulum Amjadia, Karachi, in an interview at the Dar-ul-Ulum in April 2002. He also agreed to the rise of religious militancy during Zia's reign. 
c. Impacts of State Policies on the growth and working Civil Society: Paradoxically, some CSOs grew as a result of the state's patronage while others emerged and flourished simply in reaction to the state's policies. Quite interestingly, with the state's pleasure or displeasure, both types of organizations grew tremendously in number and coverage thanks to various internal and external factors. So much so that 1980s are often misperceived as the decade of birth of civil society in Pakistan. The growth of civil society was evident in the following dimensions:

First, the civil society in Pakistan was deeply affected by and actively responded to the frontline role. On the one hand, the religious groups and Madrassah-based religious activists proliferated the country. They gained strength by joining various Afghan militias as well as the Jihadi groups also active in Kashmir and elsewhere. Brutalization of society, religious extremism, weaponization and narco-terrorism were the gifts of Afghan War to Pakistan whereas the Madrassahs experienced a boom as the nurseries of these holy fighters ${ }^{35}$.

Further, in the refugee camps set up by the Government of Pakistan in various areas of NWFP (now KPk) and Baluchistan, opened a vast field of activity for civil society in Pakistan often supported by the international donors and humanitarian agencies. But the policy of mobilizing the Afghan refugees for a Jihad against the Soviet forces in Afghanistan badly affected the role of the civil society. Pakistan (with the assistance of the western powers), supported seven Afghan resistance groups based in Peshawar and the displaced families in the camps were denied any substantial humanitarian assistance unless their men pledged to join any of these seven militias. The refugee camps turned into guerilla sanctuaries where all the relief and assistance provided to the displaced persons (DPs) was channelized through government agencies, with only a subordinate and supportive role played by the local NGOs ${ }^{36}$.

Second, the general de-politicization of the society and a rise of new middle classes thanks mainly to denationalization of business and the remittances from abroad in a way led to an increased interest in religious associations,

35 See Mahmood Mamdani, Good Muslim, Bad Muslim, Lahore: Vanguard Books, 2005, pp. 119-177. For details see Chapter Five of this dissertation.

36 Eqbal Ahmed, "Bloody Games", in Between Past and Future, op.cit. pp. 179-194 
mostly in small towns. "Imbued with a fervor unprecedented in intensity or scope, these associations carry a pursuit model of political and social life."37

Third, the imposition of Martial Law was followed by a comprehensive ban on all political parties, student associations, and trade unions. Later on by 1984 a limited and controlled political activity was allowed but strictly on non-party basis. The effect on civil society was a growth of a number of nongovernmental organizations (NGOs) under the leadership of the various politicians whose parties had been rendered defunct in a "defunct democracy". ${ }^{38}$ Many individuals whose political ambitions were unrealized resorted to the NGO business, mainly focusing on advocacy for human rights and revival of democracy through awareness creation programs. Hence, in a way, many groups of likeminded people converged and created a parallel sector in order to express their alternative vision of society 39.

Fourth, in the absence of the political parties to rally around, many candidates for representation in assemblies chose to gain support from within their regions, localities, and ethnic community vote-banks. Apart from the altruistic motives, a widespread political opportunism was also working behind the social activities of many aspiring MNAs and MPAs as Zia regime had been emphasizing social work as a criteria for the nomination to the national and provincial assemblies. This definitely marred the genuine spirit of voluntarism which had been the hallmark of Pakistani civil society in the previous eras. After the 1985 party-less general elections the successful candidates were allocated development targets, funds and employment quotas to develop their constituencies. This opened new doors of corruption when a large number of new organizations were created (many just on papers) to appropriate those funds.

Fifth, the general atmosphere of de-politicization also led to the rise of a plethora of regional, local and caste-based associations also emerged in the process. The multi-ethnic configuration of cities and failure of the state to deliver justly and equitably to all sections of the population led to a proliferation of organizations catering to the needs of particular communities and localities. Memons and Ismailies were already in the field. Many new comers like Delhi Sodagaran (traders), Rajput Welfare Association, Jaipur and Jodhpur Welfare Associations, Sindhiani Tehrik, Paracha Brothers'

\footnotetext{
Rais, op.cit.p. 191

38 Benazir Bhutto's famous statement in her book The Daughter of the East, London: Hamish Hamilton, 1988

39 Report on the State of Citizen Sector in Pakistan, 1999, NGORC, p. 23
} 
Association, Tanzim-e-Naujawanan-e-Wadi-e-Neelam (Abbottabad), etc, joined this group. All over the country, localized welfare associations emerged in big and small districts. The aims of these organizations varied from promotion of literacy to provision of healthcare services, maternity homes and income generation for the poor etc. In urban areas, community or caste-based organizations (CBOs) emerged mostly in slums and mohallas (urban localities). The failure of public sector as well as the municipal system ${ }^{40}$, led the communities to evolve their own pressure groups and selfhelp initiatives. Many groups came together to settle issues of land claims and settlement rights, others worked for provision of drinking water, sewage, health and education facilities and so on.

Sixth, some ethnic organizations in the process of time and experience developed a degree of militancy. Some were organized on ethnic bases. For example, the Mohajirs (Urdu-speaking immigrants from Indian provinces) perceiving themselves as deprived, organized well-coordinated social service and student groups ${ }^{41}$ representing their large community in Karachi, Hyderabad and Sukkar. With the passage of time and events these groups became increasingly militant and started wielding political power. Many other communities followed suit like Jeeay Sind Tehreek in interior Sindh, Saraiki, Hazara, Pakhtoon and Baluch associations etc. In the absence of broad-based political parties most of which were condemned to abeyance, and the easy availability of weapons (thanks to Afghan war), this trend made the political atmosphere ethnically charged and led to unprecedented violence challenging the legitimacy of the state itself.

Seventh, as mentioned above the demographic patterns were drastically altered by the universal phenomenon of urbanization. In Pakistan the impacts of urbanization became clearly visible by 1980s in the form of depleting manpower in the countryside on one hand and a rise of overcrowded multi-ethnic megacities on the other. In Karachi, the largest city of Pakistan, the layers of incoming settlers were not only taxing the resources and causing a break down in already insufficient public services but also creating and aggravating ethnic tensions often leading to severe law and

40 Local Government elections were held in 1979 and 1984 but more with the purpose of co-option of parallel 'collaborative' elite to counter the defunct political leadership. See Ayesha Jalal, Democracy and Authoritarianism in South Asia, Cambridge University Press, 1995, p. 103

41 Khidmat-e-Khalq Committee and APMSO (1978) preceded the formation of Mohajir Qaumi Movement in 1984 
order problems. The state-failure in addressing the issue led the Civil society to come forward to fill this gap. While the general trust enjoyed by the state as the provider of basic necessities and a guarantor of peace and order was shattering, the need for some alternative agency led to a multiplication of CSOs and an expansion of the role of civil society to new fields of nonprofit activity. The ethnic tensions, arson and blood-letting violence of 1980s (especially in Karachi and some northern areas like Gilgit), often paralyzed the city life, educational institutions and economic activity. Every time the CSOs like the Edhi Foundation played an exemplary role in providing relief, rehabilitation and reconstruction services. One man Abdus Sattar Edhi and his Edhi Foundation took a lead in working tirelessly and dauntlessly amidst bloody violence. The ethnic riots of December 1986 in various parts of Karachi resulted in fatal destruction and death. ${ }^{42}$ Abdus Sattar Edhi's ambulances and relief teams were the most trusted upon agencies and perhaps the only ones allowed in the curfew areas.

A number of other voluntary organizations like the Fatamid Foundation, Aga Khan Foundation, etc, were also active.

Eighth, exodus to Middle Eastern job markets, the Dubai-Chalo factor that became prominent in the 1980s thanks to the state-patronage, also signified a general response to the state's failure to eradicate poverty and provide employment and job security to the increasing population. The increased migration of skilled and unskilled labor particularly to the Persian Gulf states undermined the role of state as a major actor in the development process and changed the social architecture of Pakistani society ${ }^{43}$. Creating a new middle class, both urban and rural, "this process extended the spatial frontiers of livelihood and consciousness". Moreover, a part of remittances from abroad was now willingly spent on philanthropist and social welfare purposes. The $n$ (OPP Report 1987)ouveau riche element began to advance a social and political challenge to the traditional suppliers of wealth and power ${ }^{44}$. Thousands of expatriates from all the provi (Addleton 1992)nces of Pakistan gained a degree of social mobility and their remittances improved the lives and living conditions of their families and their localities. The Overseas

42 The violence reportedly costed 150 lives, damaged about 1307 houses and 1768 shops. See OPP Report , 1987, p. 1

43 Jonathan S. Addleton, Undermining the Centre - The Gulf Migration and Pakistan (Karachi: Oxford University Pro1992, cited in Rais, 1997, op.cit. pp. 189-190

$44 \quad$ Ibid, p. 190 
Pakistani Foundation started to provide facilities and guidance to these expatriates. Many other organizations followed suit.

Ninth, in Pakistan, the welfare state remained an ideal but never a reality. Hence, the co-opted. party-less government of Prime Minister Mohammad Khan Junejo ${ }^{45}$, in order to gain a degree of legitimacy, initiated his famous 5point Program for the socio-economic development. For this purpose funds were mobilized from domestic and international sources. The program included free distribution of small plots of land to the poor, a widow and orphan welfare program, education through Nai Roshni (new light) - the name given to the series of primary schools opened for the poor) Schools, healthcare, village electrification etc. As a result "a low quality infrastructure emerged where schools, clinics and hospitals were built" 46 .

But the main flaw in the program was that it entirely excluded community participation while the elected representatives were directly involved. The result was utter failure, which had two main impacts: first, the involvement of the successive governments over the last few decades in the social uplift programs not only increases the burden on the already shattered economy but also led to an inertia within the traditionally self-sufficient rural society. The availability of government funds and facilities created dependence on political largesse and eroded the age-old self-help spirit of the village. Second, the failure of such plans led to a general disappointment toward the idea of welfare state, and viability of the representative system itself where the assembly members seemed to be more interested in social work and community development (which definitely involved bottlenecks) rather than legislation.

It was at last realized that a participatory approach involving both the government and the NPS was inevitable. This culminated in two major development programs during 1980s: The Aga Khan Rural Support Program (AKRSP) covering the northern areas of Pakistan; and the Orangi Pilot Project (OPP) covering a large slum area in Karachi. Both followed the organizational model for community development. Such a mode is

45 General Zia after postponing his promised general elections for several times, and after establishing himself safely as the President of Pakistan through the controversial 8th constitutional amendment and the referendum of 1984, allowed the non-party elections in 1985 wherein his sponsored candidates won majority in the parliament and elected Mohammad Khan Junejo as his loyal Prime Minister.

46

NGORC Report 1999, p. 23 
responsive to the expressed needs of the beneficiaries through a strong organization capable of making the program work by identifying and articulating the problems and exploring and coordinating for the solutions. Here in the targeted beneficiaries must form a community organization (CO) in partnership with a support organization of the outsiders (an NGO).

Tenth, in the field of education several fresh initiatives were taken. Denationalization brought the restoration of a number of institutions like the Christian and Parsi and some local nonprofit schools to their original owners. Many new organizations working in the field of formal and informal education appeared. The Teachers Resource Center, (Karachi) and Alif Laila Publications, (Lahore) strove for the improvement of education through a number of programs

Last but perhaps more amazingly significant is the rise of advocacy and rights-oriented CSOs under Zia regime. Martial Law Ordinance of 1977 banning all forms of labor agitation as severely punishable offense caused a wave of indignation in the labor force. Workers were deprived of their right of strike and union activities in industrial and financial organizations like PIA, PTV, and Security Printing Press were banned. In 1980s Export Processing Zones were initiated but no legal rights were allowed to the majority of workers, mostly women, in these zones.

Strikes and demonstrations demanding the repeal of the Martial Law Ordinance (1977), as well as for a new set of land reforms were followed by arrests and dismissal of a number of labor leaders. National Trade Union Federation retaliated with countrywide protests. A Mazdoor Rabita Committee (labor communication committee) was formed and the struggle continued amidst worst form of state suppression. The restrictions on Press led to protests from All Pakistan News Paper Employees Confederation and Pakistan Journalist Unions' Federation under the leadership of Minhaj Burna, Nisar Usmani and Rashid Ahmed etc. Editors, journalists and Press workers held rallies, processions and hunger-strikes. They were dealt with the iron hand of the state. Many were arrested, tried in special courts and even flogged in Public. Meanwhile the struggle took a socialist color due to the presence and efforts of the disgruntled left of the country and the slogans were raised against the western capitalist imperialism and the statesuppression of the workers and peasants. However, the movement was forcefully crushed by the same tools of suppression and torture while the masses were fooled with the rhetoric of the Islamic Ideology. 
Soon the bar associations and teachers' Federations joined the struggle particularly against the denationalization process. Sindh and Baluchistan Teachers' Coordination Committee started a large-scale protest. Similarly, denationalization and the rise in fees charged by the academic institutions brought many student federations to streets. The DSF, PSF, NSF, PkSF and BSO, eventually stood for the end of Martial Law and restoration of civil liberties while the Martial Law Ordinance \# 53 (1982) declared a death penalty for involvement in "anti-state activities" which were vaguely defined. The agitators were warned that they could get their rights only on the basis of Islamic Principles.

Recognition from the World Congress of Trade Unions (1982) condemning violation of trade union and civil rights in Pakistan and demanding restoration of labor rights was a great encouragement to all of the abovementioned resistance movements. In 1983 a countrywide Movement for the Restoration of Democracy (MRD) was launched collectively by a number of then defunct political parties under the leadership of PPP ${ }^{47}$. The workers movement got impetus from the MRD and vice-versa.

The poor record of human rights and civil liberties in the country brought a spate of daring organizations in all the four provinces to the fore-front of the struggle. One of the earliest endeavors was the renowned Ansar Barni Trust established in 1980. Ansar Barni ${ }^{48}$, having seen and experienced the plight of common prisoners in the jails of Pakistan, was inspired to initiate a struggle for the rights of the prisoners, a novel idea in Pakistan at that time ${ }^{49}$. Pakistan Institute of Labor Education and Research (PILER), established in 1982 was a combined trade-union and civil-society initiative focused on research and advocacy of workers' rights and issues related to them. It endeavored to mobilize workers through intellectual and social action. PILER runs an educational program for workers all over the country and also operates Working Children Centers (WCCs) in Karachi to provide basic

47 Eleven political parties (with the PPP in lead) allied in 1983 against Zia's authoritarianism in the MRD making it one of the largest non-violent movements in South Asia. The movement faced harsh repression by the regime and was quelled within two years. For details see,: Khalid Bin Sayeed, "Pakistan in 1983: Internal stresses more serious than external problems". Asian Survey, Vol. 24, No. 2, A Survey of Asia in 1983, Part II, 1984, 219 - 228.

48 Ansar Burni, a Karachi-based advocate, himself faced detention on political grounds a couple of times after the imposition of Martial Law in 1977.

49 http://www.ansarburney.org accessed 19-02-2015 
education and recreational facilities to working children. ${ }^{50}$ Establishment of the Human Rights Commission of Pakistan (HRCP) in1986 was another major step. Working on the basis of the International Declaration of Human Rights and related international charters, covenants, protocols and resolutions HRCP has fought a long war against the authoritarian regimes and vested interests to establish the internationally accepted human rights norms in the country ${ }^{51}$ HRCP has well established chapters in all provinces and works in a wide range of fields in connection with democracy, constitution, legal matters, fundamental rights, women and children rights, minorities, labor, social security etc. It has been the vanguard organization raising voice and helping other groups in doing so, against all kinds of injustices prevalent in the society. HRCP's own research and fact-finding missions are aimed at seeking first-hand information from every possible means, sometimes from remotest quarters, conflict-ridden areas and victims of violence and presenting unbiased analysis base on factual reports. HRCP's annual reports on State of Human Rights in Pakistan, and its news-letters, its mouth-piece Jehd-e-Haq (Struggle for the truth or right) in Urdu and Sindhi are part of its continuous efforts in awareness creation and primary sources for research. ${ }^{52}$

Another paradox shows that the number and struggle of women's organization swelled while the state of women's rights deteriorated in the country. Women were among the sole victims of Zia's Islamization zeal. The controversial Hudood Ordinance (1979), Law of Evidence (1984), venomous speeches of obscurantist mullahs from the state-sponsored media, dresscodes, and the attempts to confine women to Chadar and Char-diwari ${ }^{53}$, all these factors spoke of severe limits on women's liberty and rights. The general atmosphere became so charged with anti-women sentiment that even the women from respectable families were offended and harassed in the streets and market-places with perfect impunity ${ }^{54}$. This oppressive

50 Iqbal, Khan and Javed, op. cit. p. 32. Also see the PILER website on http://www.piler.org.pk/ 1988 access 20-02-2015

51 I.A. Rehman, the Chairman HRCP narrated the long struggle of his organization in an interview with the author in his Lahore office in May 2002

52 See HRCP website, http://www.hrcp-web.org/default.asp accessed 20-2-2014

53 Chadar is a large piece of cloth worn over the normal dress while chardiwari meant the confines of four walls or homes. This was the symbolism used to define the perfect model of a modest woman living within the parameters of an Islamic society.

54 This was revealed by several ladies working in the women NGOs that in some cases women without head-coverings were abused and even slapped on the streets of Karachi. Also see Mumtaz and Shaheed, op.cit. pp. 71-72 
atmosphere became the very cause of mushroom growth of women rights organizations.

Eventually a re (HRCP n.d.)markable feminist movement emerged that shook the power avenues of the reactionary regime. Women's Action Forum (WAF) commenced a tireless struggle against all forms of violations of women's rights and liberties. Supported by many old organizations like APWA, Women's Employees' Association, and Business and Professional Women's Federation, WAF activists held demonstrations against discrimination against women in all the big cities of Pakistan.

Abida Hussain, Chairman of Jhang District Council and the sole directly elected female member of the National Assembly of Pakistan, declared that the "women in Pakistan are in the midst of fighting the biggest Jihad in history" 55 It was indeed a Jihad in face of the venomous criticism and punitive decrees issued by some state-sponsored maulanas (religious scholars) ${ }^{56}$. By the end of Martial Law (1985), women's movement had established a firm foundation of opposition to potentially discriminatory laws. The proposed Shariat Bill and the $9^{\text {th }}$ Amendment were challenged. 28 organizations including women's organizations, lawyers' associations, trade unions, students, cultural and literary bodies issued a joint statement against the Shariat Bill on the ground that it neglected the principles of justice, democracy and fundamental rights and that it would give rise to sectarianism and divide the country. WAF started a Legal Aid Cell to help women victims of discrimination. Ten women's organizations in Lahore passed a resolution against the $9^{\text {th }}$ amendment calling it "extremely injurious" to the rights and status of women in Pakistan ${ }^{57}$.

\section{Towards Conclusion:}

Comparing the growth and working of civil society under the two dictatorial regimes, clearly demonstrates its remarkable resilience and viability in Pakistan. Despite authoritarian military regimes, the decades of 1960s and 1980s witnessed a growth of civil society initiatives in Pakistan. In both cases

55 Anita M. Weiss, "The Transformation of the Women's Movement in Pakistan", in J. Henry Korson (ed.), The Contemporary Problems of Pakistan, Boulder: Westerview Press, 1993, p 99

56 For instance, according to one Fatwa (religious decree) the marriages of women demonstrating against the Law of Evidence were declared null and void.

57 Anita M. Weiss, op.cit, 101-102 
the military regimes seem to suffer from a paranoid obsession with security and abhorred the advocacy and rights-oriented movements and organizations. This leads to a confrontational model of state-civil society nexus where the success of rights-oriented CSOs is seen as the defeat of the authoritarian state and vice-versa. On the contrary the welfare and service delivery organizations were patronized and allowed greater freedom of action as such organizations preferred to share the burden of the state without challenging its legitimacy. Hence a coordination or interdependence model of state-civil society relations seems to work mostly in case of welfare and service-oriented CSOs. However, Ayub's era seems to be rather more inspired by the Keynesian economic model where the role of state in providing the public goods supersedes the role of civil society. On the other hand by the time General Zia assumed power, the world had moved towards a post-Keynesian free market economic paradigm and hence due to the tremendous influence of the west state allowed more space to the welfare and service-oriented CSOs. By the eighties the citizen movement had finally came of age availing itself the blessing in disguise of the suspended political activity. Meanwhile the international rise of neo-liberal critique of the welfare state and the rising tensions of the cold war provided a conducive atmosphere for the informal initiatives all over the world. The disappointment from the ability and credibility of the state to deliver the basic necessities of life to the downtrodden led to a probe into other options. Hence, in Pakistan, all fields of nonprofit activity ranging from charitable endowments, individual philanthropy, religious and secular welfare services, and development oriented initiatives, to the human rights activism flourished in an unprecedented manner though for diverse reasons.

It is ironical yet understandable that the tremendous growth of bold advocacy type NPOs was recorded during a period when civil liberties were non-existent. Ayub and Zia, like all unrepresentative rulers suffering from an acute insecurity syndrome, wasted no time to suppress all forms of opposition from the non-cooperative political parties, trade and student unions to non-conformist intelligentsia. Further, the drive for so-called Islamization put severe restrictions and disability on the already marginalized and vulnerable sections of the society including women, minorities etc. Under these precarious conditions many activist groups undertook the responsibility of creating awareness and building up an articulated resistance from the civil society. 
Nevertheless, the positive impact was an extension of the role of civil society to fill the gap created by the failure of government-run development programs. In fact this change also reflected an international trend: In the face of widening gap between the social needs and social provisions, the public sector was losing the confidence of the people. This led to an increased emphasis on de-regulation, and privatization, and a realistic policy admitting the public sector's limitations. Under the impact of globalization, the international donor agencies were "pressing the third world governments to rethink their service delivery role and farm out unwieldy development projects to the citizen sector". ${ }^{8}$ This also marked a death knell to the welfare state ideology.

The above discussion shows that throughout these two eras, the country was going through a complex process of political and socio-economic changes affected by various internal and external factors. From the role of the 'most allied ally of America in sixties, to a frontline state against the Soviet onslaught to that of a bastion of Islamic fundamentalist ideology, the statesociety relations in Pakistan were drastically altered. Constitutional and Penal Code amendments, suppression of independent political activities, marginalization of vulnerable sections, reversal of Bhutto's economic measures through denationalization and deregulation of economy caused unequal development, demographic changes, rise in ethnic consciousness, religious extremism etc. all led to an array of ideological and social confusions within the society. The distinction between the left, the right and the centre blurred while opportunist attitudes gained currency.

In these conditions the NPS also underwent basic ideological and structural changes. Pakistan's international entry to the cold war alliances in sixties and its entry to the Afghan War in eighties made it a favored nation for both military and economic assistance. Both regimes' preoccupation with the external politics, suppression of resisting political elements with impunity and willingness of international donors to assist private initiatives left a wide field of social development and service delivery open to the private sector.

58 NGORC, State of Citizen Sector in Pakistan, 1999, p. 25 
Response from the latter was the mushroom growth of CSOs and availability of foreign funds enhanced this trend. However, while the civil-society overall experienced a boom, rise of professionalism and erosion of voluntarism in the civil society at large emerged as significant corollary. Both regimes endeavored to use the civil society to further their own interest of depoliticization and atomization of the potential resistance and movements for the restoration of democracy and fundamental freedoms. Nevertheless, there were many old and new organizations that remained bulwarks of voluntary zeal as well as stubborn resistance. 


\section{References}

Addleton, Jonathan S. Undermining the Centre - The Gulf Migration and Pakistan. Karachi: OUP, 1992.

Ahmed, Eqbal. "Bloody Games." In Between Past and Futurev-Selected Essays on South Asia, edited by Dohra Ahmed, Iftekhar Ahmed, \& Zia Mian, 179-194. Karachi: OUP, 2004.

Bhutto, Benazir. Daughter of the East. London: Hamish Hamilton, 1988.

Brinkerhoff, Derick W. "Exploring State-Civil Society Collaboration: Policy Partnerships in Developing Countries." Nonprofit and Voluntary Sector Quarterly 28, no. 01 (December 1999): 59-86.

Cohen, Alix A. "Kant's Concept of Freedom and the Human Siciences." Canadian Journal of Philosophy 39, no. 01 (n.d.): 113-135.

Gellner, Ernest. Conditions of Liberty: Civil Society and its Rivals. London: Hamish Hamilton, 1994.

Gould, Harold. "Civil Society in Pakistan and India: A study in contrast." Briefs of the Centre for South Asian Studies, January 2007.

HRCP. HRCP. 2014. http://www.hrcp-web.org/default.asp (accessed 02 20, 2015).

Iqbal, Asif, Hina Khan, and Surkhab Javed. Nonprofit Sector in Pakistan: Historical Background. Johns Hopkins Comparative Nonprofit sector Project, Working Paper No. 4 , Karachi: Social Policy and Development Centre (SPDC), 2004.

Jalal, Ayesha. Democracy and Authoritarianism in South Asia. Cambridge: Cambridge University Press, 1995.

Mamdani, Mehmood. Good Muslim Bad Muslim. Lahore: Vanguard, 2005.

O'Donnel, Guillermo, and Philippe C. Schmitter. Transitions from Authoritarian Rule: Tentative Conclusions about uncertain democracies. 2013. Baltimore: Johns Hopkins University Press, 1986. 
OPP Report. Karachi: Orangi Pilot Project, 1987.

Oxhorn, Philip D. Organizing Civil Society - The Popular Sectors and the Struggle for Democracy in Chile. Pennsylvania: Pennsylvania State University Press, 1995, 2003.

Raes, Rasool Baksh. State, Society and Democratic Change in Pakistan. Karachi: OUP, 1997.

Saeed, Khalid bin. "Pakistan in 1983: Internal stresses more serious than esternal problems." Asian Survey, 1984: 219-228.

Shahjahanpuri, Abu Salman, and Amir-ul-Islam Siddiqui. Barr-e-Sagheer Pako-Hind ke Ilmi, Adabi aur Taleemi Idare - Mujalla-e-Ilm-o-Agahi. Vol. 2. 2 vols. Karachi: Government National College, 1975.

Tocqueville, Alexis de. Democracy in America. Translated by Henry Reeve. n.d.

Weiss, Anita M. "The Transformation of the Women's Movement in Pakistan." In The Contemporary Problems of Pakistan, edited by J. Henry Korson. Boulder: Westeview Press, 1993.

Zaidi, Akbar. Issues in Pakistan's Economy. Michigan: OUP, 1999. 